by Thomas J. Suttner ${ }^{1}$, Erika Kido ${ }^{1}$, Peter Königshof ${ }^{2}$ and Werner E. Piller ${ }^{3}$

\title{
Mid-Paleozoic climate change and biodiversity patterns (IGCP 596): Conferences and Collaborations in 2011
}

\footnotetext{
1 Commission for the Palaeontological and Stratigraphical Research of Austria (CPSA), Austrian Academy of Sciences, c/o University of Graz - Institute for Earth Sciences (Geology and Paleontology), Heinrichstrasse 26, A-8010 Graz, Austria. E-mail: thomas.suttner@ uni-graz.at; erika.kido@uni-graz.at

2 Senckenberg Forschungsinstitut und Naturmuseum, Senckenberganlage 25, 60325 Frankfurt am Main, Germany. E-mail: Peter.Koenigshof@senckenberg.de

3 University of Graz - Institute for Earth Sciences (Geology and Paleontology), Heinrichstrasse 26, A-8010 Graz, Austria. E-mail: werner.piller@uni-graz.at
}

The new Project 596 (2011-2015) within the International Geoscience Programme (IGCP) started in April 2011. It focuses on climate change and biodiversity patterns in the Mid-Paleozoic (Early Devonian to Late Carboniferous). Here we provide a summary of activities during the Opening Meeting. The first annual conference resulted in a consolidation of a global network including researchers of other large projects such as IGCP 580 and IGCP 591. Until now the group of participants interested in collaboration counts 135 scientists of 26 countries of which more than one-third are women in science. Participants come form Australia (2), Austria (3), Belgium (10), Bulgaria (2), Canada (1), China (1), Czech Republic (12), Estonia (1), France (13), Germany (11), Iran (1), Italy (5), Japan (7), Malaysia (1), Mongolia (4), Morocco (1), Myanmar (1), Poland (8), Portugal (2), Russia (10), Spain (19), Thailand (4), Turkey (3), United Kingdom (3), U.S.A. (9), and Vietnam (1). In order to secure the future of the international collaboration within IGCP 596, further financial support is acquired by project-grants from national science institutions of several countries. In addition to the achievements during the Opening Meeting, a short overview on other joint conferences held in 2011 and those scheduled for 2012 is given.

\section{Introduction}

The recently started IGCP 596 (2011-2015) project is specifically interested in the interaction between climate change and biodiversity in the Mid-Paleozoic (Early Devonian to Late Carboniferous). As one of the most intensely studied periods, the Mid-Paleozoic conforms to an interval of dynamic long-term climate change which was accompanied by substantial variations in biodiversity. Within the duration of the project, we intend to increase the record of biodiversity in all kinds of fossil groups and clarify links between specific biodiversity patterns and climate change. Groups distinctive for different ecosystems, especially indicating terrestrial, neritic and pelagic marine environments, are land plants, phytoplankton, foraminifera, sponges, corals, arthropods, cephalopods, echinoderms, brachiopods, bryozoans, conodonts, and fishes. In addition to the enhancement and revision of the existing fossil database we also include other methods for paleoclimate modeling such as geochemistry and geophysics.

We already recognized that the Opening Meeting and subsequent joint meetings held in 2011 encouraged Devonian and Carboniferous workers to a high productivity. The achievements of project participants during the first year resulted in a large number of highquality peer reviewed publications, e.g., Bahrami et al. (2011), Baranov and Blodgett (2011), Blieck (2011), Brice and Mottequin (2011), Casier et al. (2011), Corriga et al. (2011), Ernst et al. (2011), Garcia-Alcalde (2011), Ivanov et al. (2011), Izokh et al. (2011), Kido and Suttner (2011), Liao and Valenzuela-Ríos (2011), Martínez-Pérez et al. (2011), Poty et al. (2011), Schemm-Gregory (2011), Tolokonnikova et al. (2011), Vodrázková et al. (2011), Wongwanich and Boucot (2011), and Yolkin et al. (2011). Similar to the preceding project IGCP 499, special volumes like the one edited by Brett et al. (2011) or by Königshof (2009) are planned for the near future.

\section{Results of the IGCP 596 Opening Meeting}

The Opening Meeting was organized by Thomas J. Suttner (Austria), Erika Kido (Austria), Werner E. Piller (Austria) and Peter Königshof (Germany). The meeting was held in Graz, Austria from $19^{\text {th }}$ to $24^{\text {th }}$ of September 2011 (Fig. 1). The general programme consisted of a three days scientific session and a field-workshop in the Carnic Alps (Austria-Italy). In total, 36 delegates from 13 countries joined to the first part of the meeting: Austria (6), Belgium (6), Bulgaria (1), Czech Republic (3), France (1), Germany (2), Japan (3), Mongolia (2), Poland (1), Russia (5), Spain (2), Turkey (2), and U.S.A. (2). These included 15 women in science and $5 \mathrm{PhD}$ students (Fig. 2). 


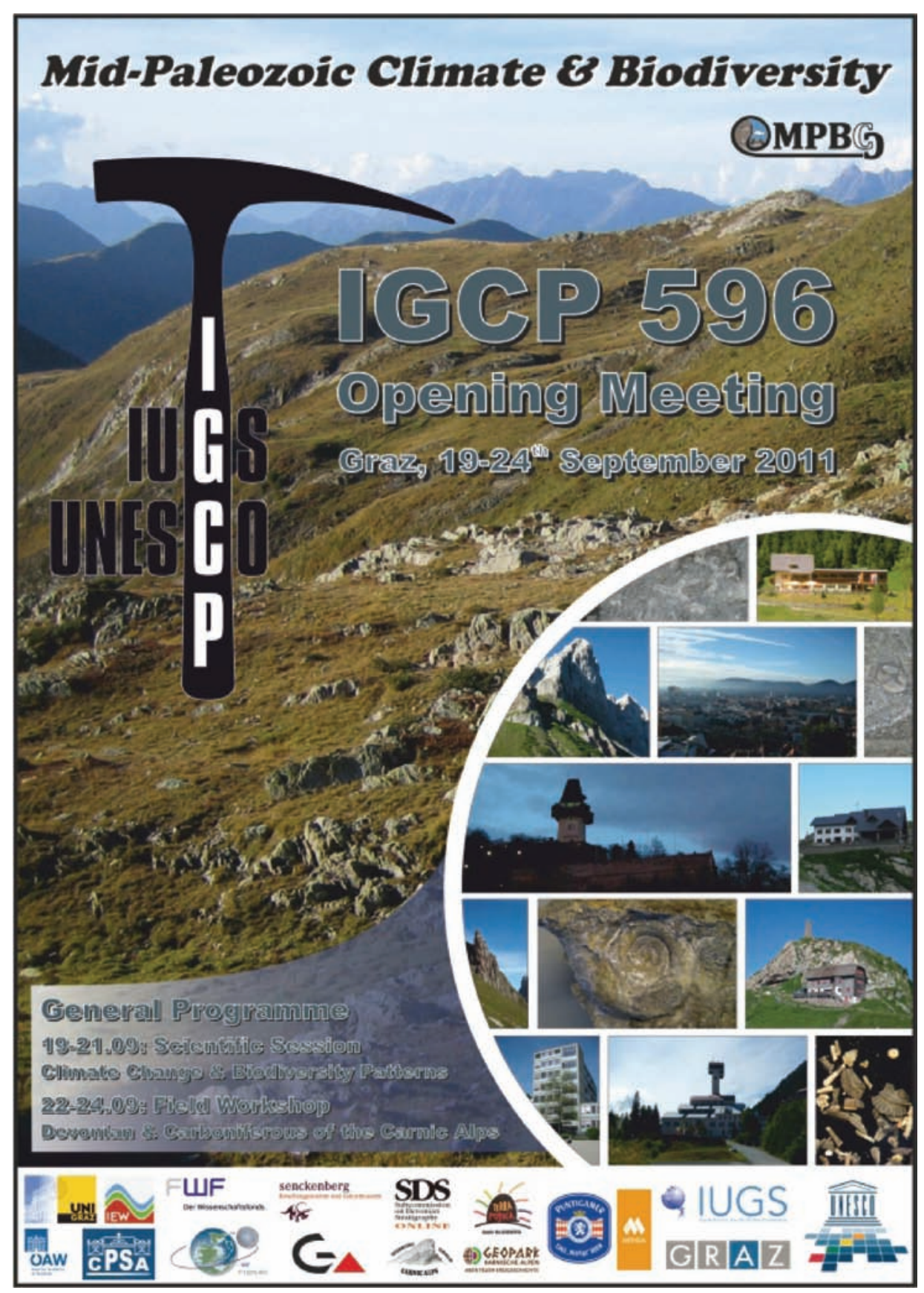

Figure 1. IGCP 596 Opening meeting announcement wall-chart.

Major topics of the conference were the "state-of-the-art" of biostratigraphy, biodiversity patterns and evolution of fossils, as well as the impact of global events on marine organisms during the Devonian to Carboniferous, focusing on a multidisciplinary approach by including geochemical and geophysical methods (joint session with IGCP 580). The scientific session was led by the scientific committee consisting of five members: Iliana A. Boncheva (Bulgaria), Leona Koptiková (Czech Republic), Toshiyuki Kurihara (Japan), Carine Randon (France) and Johnny A. Waters (USA). Different from the commonly known style of conferences also the poster-presenters had to give a 3-5 minutes oral introduction in front of their poster. Among the participants of the first part of the meeting, 18 persons joined the field workshop and visited the pre-Variscan sequences of the Carnic Alps.

\section{Scientific Sessions}

The scientific sessions have been divided into 4 units (see below). Therefore each session started with a special keynote lecture which was given by an expert in each field.

Session 1, "Biodiversity patterns and evolution of fossils", started with the keynote lecture by Yarinpil Ariuchimeg (Mongolian Academy of Sciences, Mongolia). She summarized Carboniferous fossils of marine and terrestrial deposits, such as brachiopods, bryozoans, fusulinaceans, corals and floras, explaining their affinities between Mongolia, Siberia, Angara or the Tethyan province. Presentations related to the biodiversity patterns of different fossil groups such as the Middle Devonian bryozoans of Eifel area in Germany, Devonian conodonts and Late Devonian-Early Carboniferous foraminifera of the South Urals were provided in this session. The biodiversity of fossils which occur in the Paleozoic strata of Austria was also summarized. Other interesting topics treated the evolution of the Devonian-Mississippian echinoderm community, habitats of the DevonianCarboniferous tubeworms in marine environments, origin of the Mississippian radiolarian cherts in Europe, and conodont stratigraphy, microfacies, and isotope geochemistry of the Late Devonian pelagic carbonates in northwestern Thailand.

The second keynote lecture by Michael Joachimski (Univ. Erlangen-Nürnberg, Germany) opened session 2, "Climate perturbations: Effect on marine organisms". He gave new insights on the Middle Paleozoic paleotemperature by providing data on oxygen isotopes from conodont apatite. In this session, Middle and Late Devonian climate perturbations which resulted in bioevents (such as Kacák, Kellwasser-, and Annulata events) were discussed in terms of sedimentary and faunal evidences. Climate change during the Devonian and Carboniferous was approached based on the formation of ironstones within carbonate platform successions in NW Anatolia and bentonites in NW Turkey.

Anne-Christine da Silva (Université de Liège, Belgium), one of leaders of the IGCP 580, held the keynote lecture for session 3, "Multidisciplinary approach: Geochemistry and Geophysics". She has discussed magnetic susceptibility (MS) signals obtained from various sedimentary settings of several paleo-locations during different time intervals, ranging from the Devonian to Carboniferous. Apart from this, sedimentology and/or microfacies of carbonate successions in Belgium, Germany and Czech Republic were compared with 


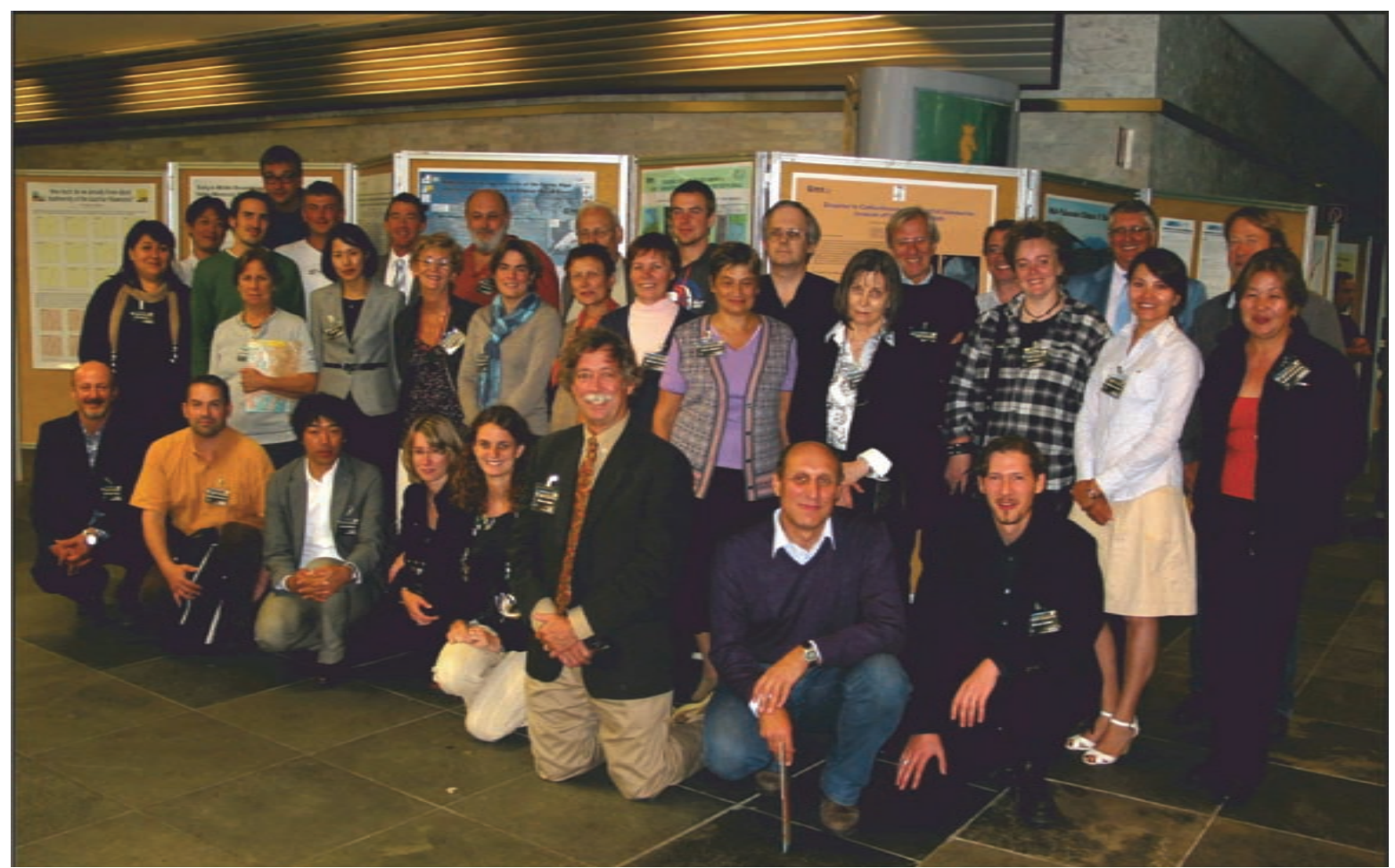

Figure 2. Conference Photo taken in front of the poster walls near the lecture hall (University Graz).

magnetic susceptibility and gamma-ray spectrometry. Ostracods, rock facies and magnetic susceptibility of the Givetian/Frasnian transition from Belgian deposits were also discussed. Another talk based on the MS study of carbonate ramp and platform deposits initiated a scientific discussion on the precessional and half-precessional climate forcing of Mid-Devonian monsoon-like dynamics among the audience. Further, a presentation on the influence of magnetic properties and mineralogical composition of insoluble residues by using different acids for the dissolution of limestones samples provided new insights on the quality of methods discussed. U-Pb isotopic dating and carbon isotope geochemistry of the Devonian deposits were also discussed during this session.

The keynote lecture of session 4, "Mid-Paleozoic bio- and lithostratigraphy", was given by Nadezhda G. Izokh (Trofimuk Institute of Petroleum Geology and Geophysics SB RAS, Russia). She has summarized biodiversity of the conodonts from the Devonian of West Siberia emphasizing on the biostratigraphic context between different localities. The distribution and facies dependence of the so called Zdimir (brachiopod) fauna from South China was also introduced. Detailed conodont biostratigraphy of the Lower and Middle Devonian of the Spanish Central Pyrenees, Devonian of Southern Urals, Middle Devonian of SE Poland and Upper Devonian of northwestern Thailand was provided by other colleagues. Other presentations concerned biostratigraphy of the Upper Silurian-Devonian of Central Mongolia and Southwest Japan based on radiolarians, as well as Lower Devonian stratigraphy based on ostracods. Evolution of Devonian depositional systems of the Italian side of the Carnic Alps was also shown.

All presentations of this first annual meeting of IGCP 596 were summarized in an abstract volume produced already in advance of the conference which includes 41 contributions (by 90 co-authors). It is available for free under: http://erdwissenschaften.uni-graz.at/ publikationen/zeitschrift/band16/index_de.php
Presently a proceedings volume with manuscripts of about 12 presentations is on the way to be edited and submitted for review to the handling editors of the ISI-journal Bulletin of Geosciences (Czech Republic).

\section{Business Meeting}

On the third conference day a business meeting was held, where delegates were invited to give short communications on recently started projects or the progress of Regional Working Groups focusing on Devonian to Carboniferous strata. Reports were given by colleagues from Russia (Nadezhda G. Izokh: Report on the SDS and IGCP 596 joint meeting in Novosibirsk; Elena I. Kulagina: Presentation on the type and key sections of the Lower Carboniferous in the Southern Urals and the Russian platform and discussion on D-C boundary tasks), Spain (José Ignacio Valenzuela-Ríos: Report on the XXVII Journadas Sociedad Española de Paleontología which was held in cooperation with IGCP 596; introduction of the Spanish Working Group) and Austria (Thomas J. Suttner: introduction of the Carnic Alps Working Group and the new project FWF P23775-B17 entitled Late Eifelian climate perturbations: Effects on tropical coral communities). Peter Königshof gave a summary-report on the IGCP 596 precursor project IGCP 499 entitled Devonian land-sea interactions and presented a general working plan for the active IGCP 596 for each research year until 2015 including announcements of forthcoming conferences and workshops (schedule for 2012 see below, or consult ICGP 596 homepage for further information). Additionally, he had also presented challenges and perspectives for young scientists that are supported by the YES initiative (http://www. networkyes.org/).

\section{Awards}

Two awards, one for best oral presentation and one for best poster 
presentation, have been granted in the course of the meeting. Since all contributions were excellent it was a difficult task for the organizing committee. Finally, the prize for the best oral presentation was given to David De Vleeschouwer (Belgium) for his discussion on Precessional and half-precessional climate forcing of Mid-Devonian monsoon-like dynamics. The award for the best poster was given to Olga Artyushkova (Russia) for the presentation of Devonian volcanism and conodont biodiversity in the South Urals. Additionally, a third prize for the best international cooperation among young scientists was raised and given to the Mongolian-Japanese working group. Delegate Nuramkhaan Manchuk (Mongolia) received it for her talk on $\mathrm{U}-\mathrm{Pb}$ isotopic dating of Devonian radiolarian-bearing Yoshiki Formation in Japan and Toshiyuki Kurihara (Japan) for the poster entitled Latest Silurian and Early Devonian radiolarian assemblages from tuffaceous rocks in the Tomochi area of the Kurosegawa Terrane, central Kyushu, Southwest Japan. We hope that other scientists will follow their example and establish such dynamic international working-groups which achieve interdisciplinary and high-quality research.

\section{Field Workshop}

After the scientific part of the meeting and a mid-conference recovery day, including city tour and conference dinner in Graz, a field workshop to Devonian and Carboniferous outcrops in the Carnic Alps followed. On the first day the entire group moved from Graz to the Carnic Alps in Carinthia. On the way we stopped at several localities for one simple reason: Geo-Tourism. First Stop was in Bad Bleiberg where we had a guided tour in the show-mine "Terra Montana" (Fig. 3). Secondly, we visited the Geopark-Center in Dellach. The subsequent stop was located close to the Austro-Italian border at the Plöcken Pass, where the entire group moved up Mount Cellon directly to the Cellon Avalanche gully (altitude: $1500 \mathrm{~m}$ ). At this locality, which is well-known by Paleozoic workers world-wide, Hans Peter Schönlaub gave an introduction on the succession of Lower Paleozoic deposits outcropping there. On the second day we moved from the Valentinalm Hut (1221 m) to Lake Wolayer (approx. 1940 m) along the Carnic Alps Geotrail. Along the mountain-path we saw different depositional environments of Devonian and Carboniferous units such as the red pelagic limestones of the Findenig Formation or the bright grey shallow marine carbonates of the Biegengebirge (Fig. 4). We took several breaks for explaining regional settings and vivid discussions followed on biodiversity patterns of marine fossil groups present in Devonian deposits of this area (Fig. 5). After the discussion participants had the opportunity to collect samples for further research or to enhance their own collections with comparative specimens. On the third day the entire group crossed the Austro-Italian border some few hundred meters south of Lake Wolayer where the morning discussion on regional tectonic development was supported by Italian Cappuccino. Additionally, we observed Late Silurian cephalopod limestones near Rifugio Lambertenghi Romanin (Fig. 6) and saw Devonian peritidal and lagoonal deposits along the path leading to the steep Spinotti trail. A final short recovery-stop (Fig. 7) was highlighted by the panoramic view to the coral bearing platform carbonates of Mount Seewarte and Mt. Hohe Warte before we moved down to the village of Collina (Friuli, Italy) from where buses brought us back to Graz.

\section{Financial Report}

During the opening meeting 5 delegates ( 4 of them female scientists) were supported by the IGCP 596 grant of the UNESCO/ IUGS. Additional support for the invitation of two keynote-speakers came from the NAWI Graz joint project of the University of Graz and the Graz University of Technology and FWF-project P23775-B17 (Austrian Science Fund). Another keynote speaker as well as one student were partially supported by the national IGCP grant of NAP0017 (subproject of IGCP 580). Other expenses regarding the organization were, additionally to the conference fee received, cofinanced by the Institute for Earth Sciences (University of Graz), FWF P23775-B17 (Austrian Science Fund), and IGCP 596 grant of UNESCO/IUGS.

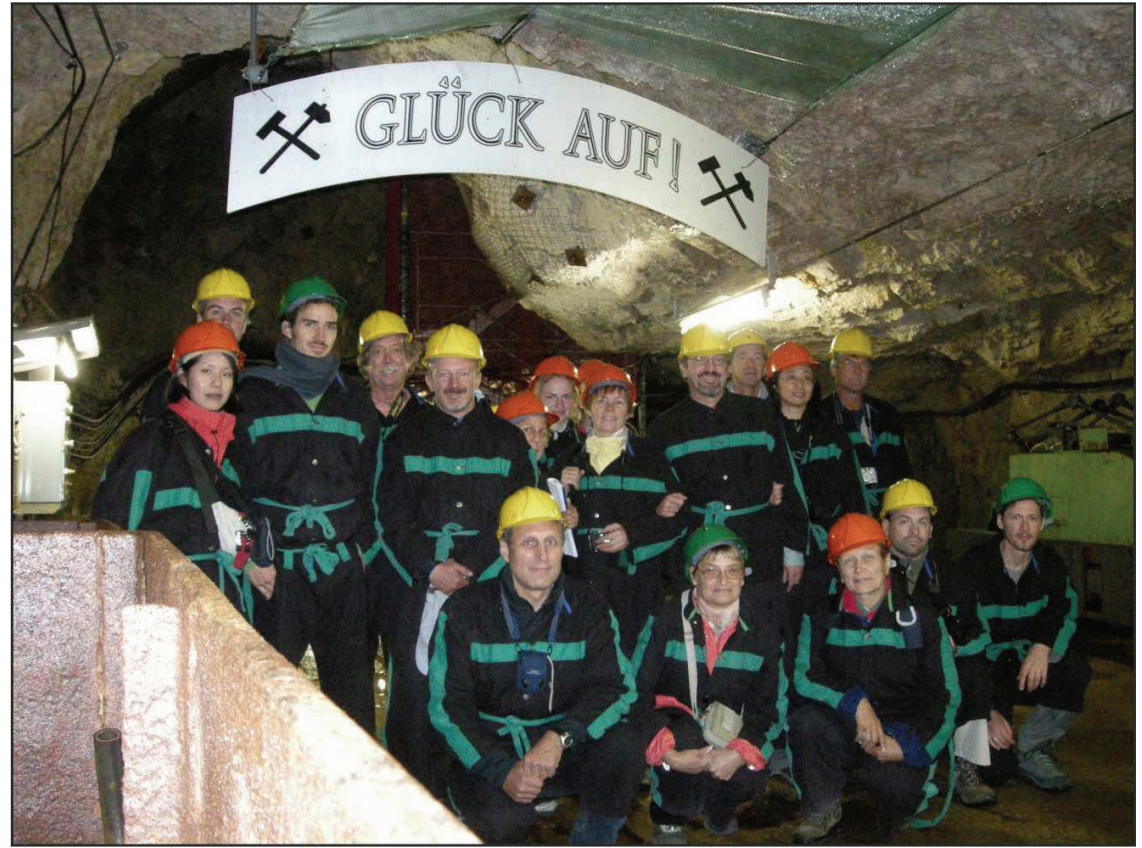

Figure 3. Group Photo taken in the show-mine of Bad Bleiberg (Carinthia).

\section{Joint meetings in 2011}

The first year of the project was also aimed to strengthen cooperation between different working groups and countries. To achieve this goal, a number of joint meetings have been organized in addition to the opening meeting. In recent years, the close cooperation of the International Subcommission on Devonian Stratigraphy (SDS) with IGCP projects with a strong Devonian focus has been highly successful. Consequently, it was decided that the long planned field symposium for 2011 in Russia, with technical sessions in Novosibirsk and excursions to the South Urals and Kuznetsk Basins, should become the first joint meeting of SDS and the new IGCP 596. The Southern Urals excursion, with four days on fossiliferous outcrops, formed the first part of the program, from the $20^{\text {th }}$ to $25^{\text {th }}$ of July. The 91 pages long excursion guidebook by Artyushkova et al. (2011) is formally published in Ufa (ISBN 978-5901900-54-3) and summarizes a wealth of data 

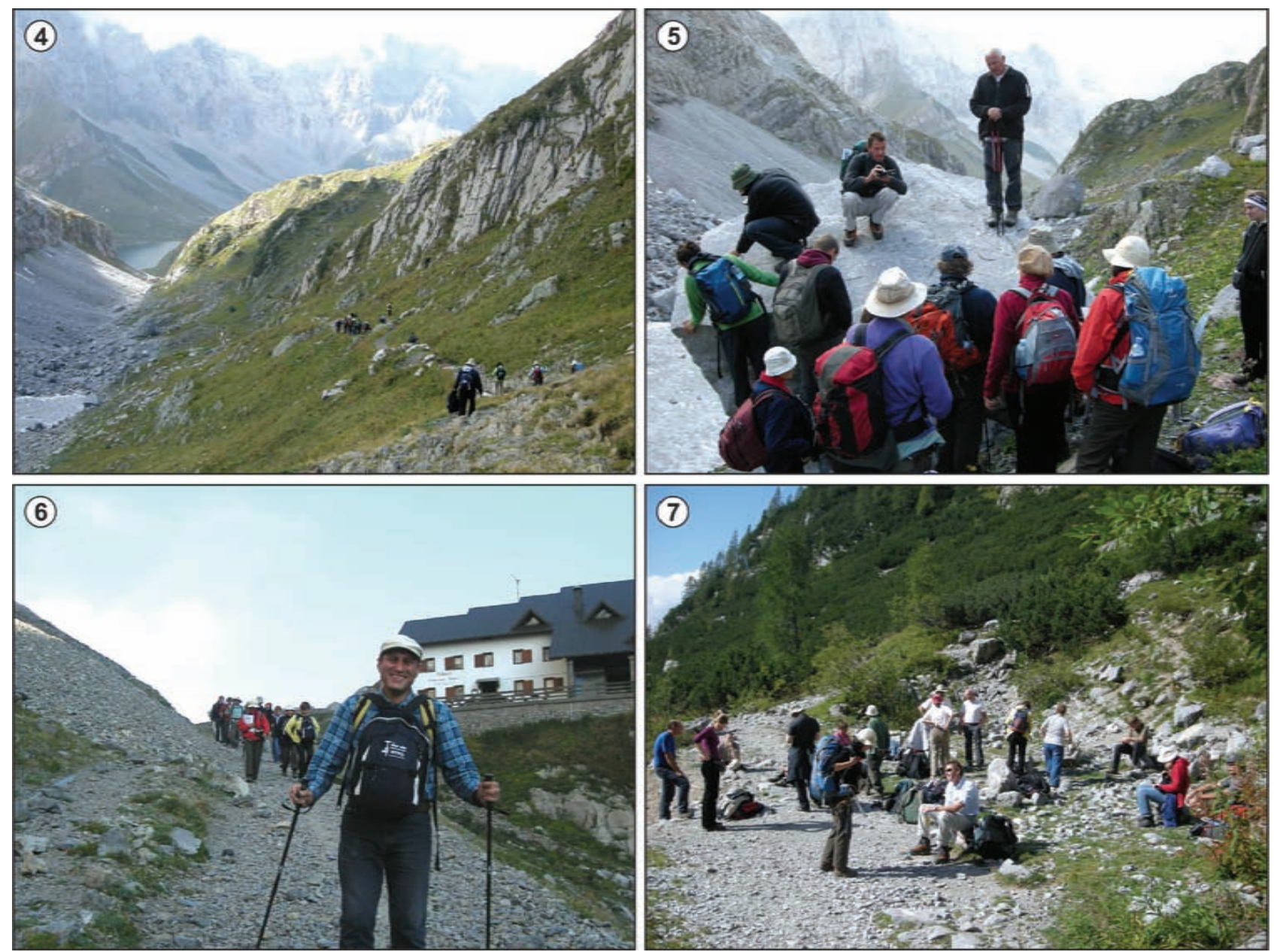

Figures 4-7. (4) Geotrail from Valentintörl down to Lake Wolayer in the central Carnic Alps. Mountain panorama in the background shows the Biegengebirge. (5) Introduction to the Lower Devonian shallow marine limestones which yield a very diverse macrofauna by Hans Peter Schönlaub (standing on the limestone boulder). (6) Pathway from Lake Wolayer across the Austro-Italian border which is allocated just behind Yury Gatovsky from Moscow (Russia). (7) Final Stop at the opposite side of Spinotti trail leading through the shallow marine platform carbonates.

that is otherwise rather difficult to obtain. The four days covered three different regions to the E/SE of Ufa: the Gabdyukovo section E of Arkhangelsk (Emsian and Frasnian formations), the Kuk-Karauk, famous Sikaza and Ryauzyak River sections of the Sargaevo region (upper Givetian to uppermost Famennian), and the Akkyr section along the Zilim River E of Karagaevka.

The meeting was attended by 62 specialists from eleven countries and took place from $27^{\text {th }}$ to $29^{\text {th }}$ of July in Novosibirsk. High-level simultaneous translations between English and Russian enabled an easy understanding of all oral presentations. The formally published (Novosibirsk Publishing House SB RAS: ISBN 978-5-7692-11874) Contributions Volume was edited by Olga T. Obut and Tanya P. Kipriyanova and includes the extended abstracts of 60 papers on 191 pages.

The post-meeting excursion led to two different crustal blocks at the southern margin of Siberia, the Salair and western margin of the Kuznetsk Basin (Kolyvan'-Tom Folded Area). It lasted from the $30^{\text {th }}$ of July to the $10^{\text {th }}$ of August and included two large camps for more than thirty participants, one near Gur'evsk (Salair) and one at the Tom River (Fig. 8) near Izvestkovy Zavod Village (Kuznetsk). The 96 pages long guidebook by Bakharev et al. (2011) is highly informative, with many new data or updates (in comparison to previous field guidebooks) and published with high quality (many color figures, section photos, logs, range charts and fossil plates) in the Novosibirsk Publishing House SB RAS (ISBN 978-5-7692-1190-4).

Another joint meeting was organized in conjunction with the $8^{\text {th }}$ Baltic Stratigraphical Conference and took place in Riga, Latvia ( $28^{\text {th }}$ - $30^{\text {th }}$ of August). In the frame of that meeting it was important to announce the new IGCP 596 in order to expand the number of IGCP participants, to foster existing cooperation and to instigate new networks. 73 scientists of 10 countries attended the meeting. An abstract volume with all contributions (oral and poster presentations) and a Post Conference Field guidebook have been published. In the frame of the conference participants also had the chance to visit the old Centre of Riga, part of the World Heritage List of UNESCO (Fig. 9). The field excursion led the participants to Devonian outcrops, with a special focus on the Middle Devonian sequences.

Since one of the major tasks of IGCP 596 is to intensify cooperation with universities and research institutions in Southeast Asia we decided to organize a Special Session in conjunction with the World Conference on Palaeontology and Stratigraphy (WCPS2011). The meeting took place from $28^{\text {th }}$ of November to $2^{\text {nd }}$ of December 2011, in Nakhon Ratchasima, Thailand. This conference was held in honor of His Majesty the King's $84^{\text {th }}$ birthday anniversary. 
A Contributions Volume was published including abstracts of 173 papers on 254 pages. About 270 participants from 24 countries attended the meeting. In the frame of this conference participants had the chance to visit scientific collections and museums (Figs. 10-11). The meeting was a good opportunity to start new cooperations. Based on earlier field work in Thailand a small group of scientists decided to intensify research within the frame of IGCP 596. We also agreed to organize an IGCP 596 field workshop in Vietnam in the near future. In 2012 a small group of scientists will pre-select some potential sections. A high number of young scientists attended the meeting, some of them may be involved in our project in future.

All these conferences and workshops will act as a catalyst for future collaborative research between different disciplines, as well as offering a network for collaboration between researchers involved in IGCP 596.

\section{Meetings and Workshops in 2012}

In 2012 several Symposia/Meetings will be held within the frame of large conferences. The first meeting is a joint session of IGCP 591 and IGCP 596 during the GSA North Central Symposium and Pander Society Meeting (Ohio, U.S.A.) from $22^{\text {nd }}$ to $24^{\text {th }}$ of April, 2012. The Theme session is entitled Bridging the Gap between the Great Ordovician Biodiversification Event and Late Carboniferous Life:
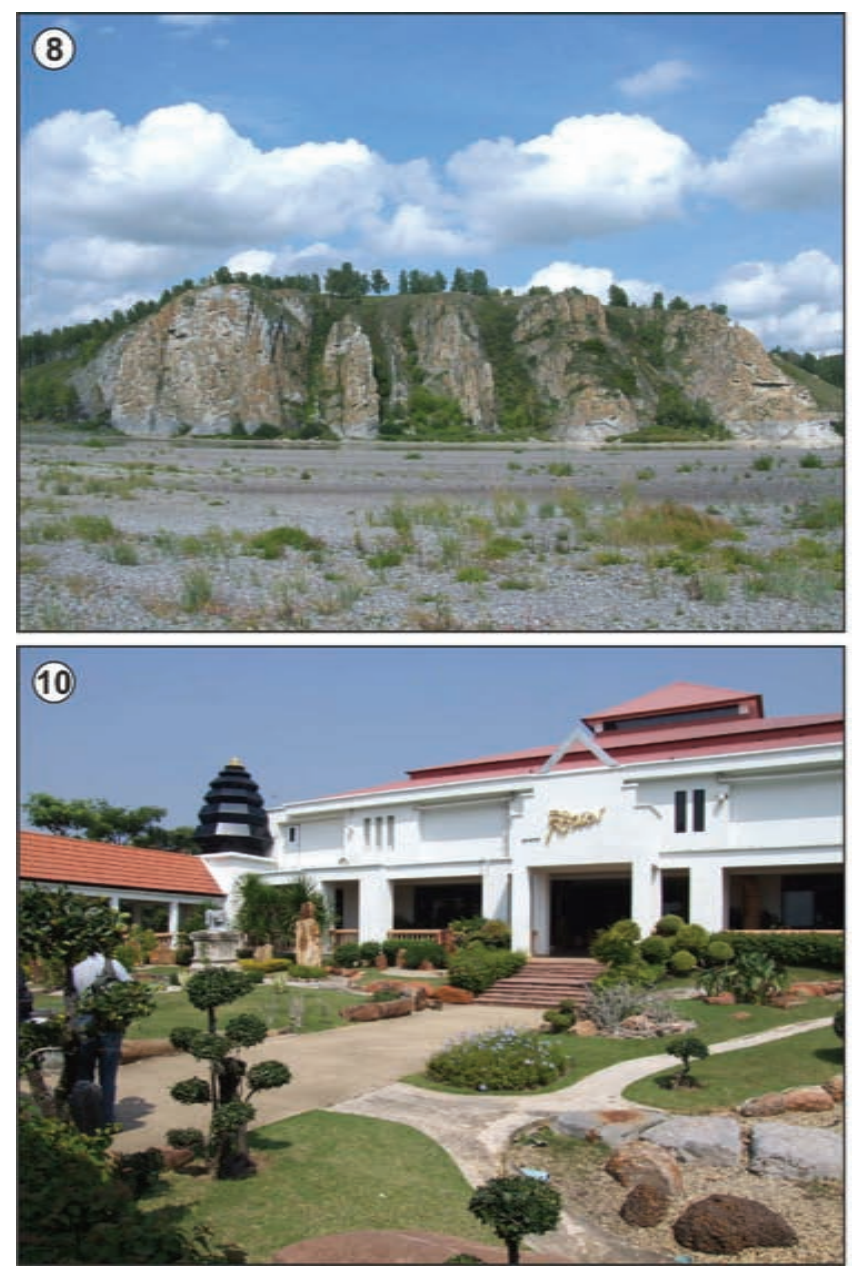

Conodonts, Climate Change, and Biodiversity Patterns [Session 9] (http://www.geosociety.org/Sections/nc/2012mtg/). The second symposium will be convened together with IGCP 580 within the frame of the IGC 34 in Brisbane, Australia $\left(5^{\text {th }}-10^{\text {th }}\right.$ of August, 2012; http://www.34igc.org/), entitled Climate change and biodiversity patterns in the Mid-Paleozoic (Early Devonian to Early Carboniferous) [Symposium 3.8]. The third symposium will take place during the Centenary Meeting of the Paläontologische Gesellschaft in Berlin, Germany (24 $4^{\text {th }}-29^{\text {th }}$ of September, 2012). The Symposium called Climate Change and Biodiversity in the Mid-Paleozoic will represent the main event of IGCP 596 for 2012 including the annual business meeting (http://palaeo100.naturkundemuseum-berlin.de/en/home/).

\section{Further Project Information}

An outline of the project, list of participants, current activities, forthcoming meetings and links to other IGCP projects and collaboration partners are accessible via the official homepage: http:// www.senckenberg.de/IGCP-596

Colleagues working on stratigraphy, paleobiodiversity patterns, paleogeography, paleoclimate, sedimentology and geochemistry in the Devonian and/or Carboniferous are welcome to contribute to the project! This can easily be achieved by acknowledging IGCP 596 in your publications, and by sending annual reports with project relevant
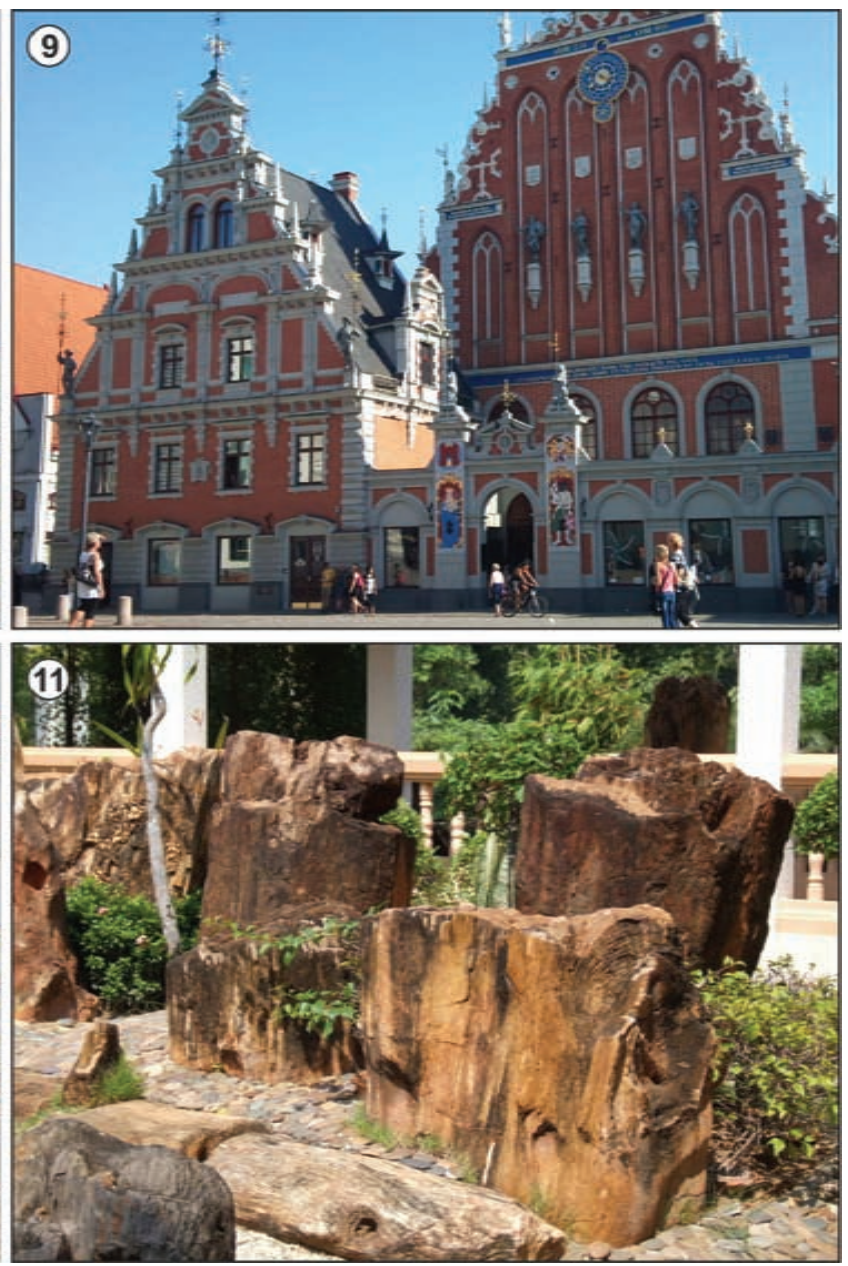

Figures 8-11. (8) Middle Devonian Reef limestones at the Tom River, Russia. (9) Old City centre of Riga, Latvia. (10, 11) The Northeastern Research Institute of Petrified Wood and Mineral Resources in Thailand offers a number of excellent exhibitions, such as on petrified wood, dinosaurs and minerals. 
activities and references to the secretariat or the coordinators of the different working groups!

Central project-coordination secretariat contact: Peter. Koenigshof@senckenberg.de

\section{Acknowledgements}

We would like to thank all project participants for attending the meetings of IGCP 596 and sharing their knowledge with colleagues all over the world. Furthermore thanks are due to all funding organizations mentioned under Financial Report.

\section{References}

Artyushkova, O.V., Maslov, V.A., Pazukhin, V.N., Kulagina, E.I., Tagarieva, R.H., Mizens, L.I., and Mizens, A.G., 2011, Devonian and Lower Carboniferous type sections of the western South Urals: Ufa, Sterlitamak, Russia, July 20-25, 2011, Pre-Conference Field Excursion Guidebook, pp. 1-91.

Bahrami, A., Gholamalian, H., Corradini, C., and Yazdi, M., 2011, Upper Devonian conodont biostratigraphy of Shams Abad section, Kerman province, Iran: Rivista Italiana di Paleontologia e Stratigrafia, v. 117, no. 2, pp. 199-209.

Bakharev, N.K., Izokh, N.G., Obut, O.T., Talent, J.A. (eds), 2011, MiddleUpper Devonian and Lower Carboniferous biostratigraphy of Kuznetsk Basin. Field Excursion Guidebook, International Conference "Biostratigraphy, Palaeogeography and Events in Devonian and Lower Carboniferous" (SDS/IGCP 596 joint field meeting - July 20 - August 10, 2011), Novosibirsk Publishing House SB RAS, 2011, pp. 1-98.

Baranov, V.V., and Blodgett, R.B., 2011, Gonella, a new genus and first color patterned terebratulidine brachiopod from the Lower Devonian of Northeast Asia: Bulletin of Geosciences, v. 86, no. 2, pp. 269-274.

Blieck, A., 2011, From adaptive radiations to biotic crises in Paleozoic vertebrates: a geobiological approach: Geologica Belgica, v. 14, no. 3-4, pp. 203-227.

Brett, C.E., Schindler E., Königshof, P. (eds), 2011, Sea-level cyclicity, climate change, and bioevents in Middle Devonian marine and terrestrial environments: Palaeogeography, Palaeoclimatology, Palaeoecology, v. 304, issues, 1-2, pp. 1-194.

Brice, D., and Mottequin, B., 2011, Rhynchonellid and spiriferid brachiopods as valuable tools for correlation of shelly faunas near the Devonian/ Carboniferous boundary: Geological Survey of Western Australia, Record 2011/20, 48

Casier, J.-G., Devleeschouwer, X., Moreau, J., Petitclerc, E., and Préat, A., 2011, Ostracods, rock facies and magnetic susceptibility records from the stratotype of Terres d'Haurs Formation (Givetian) at the Mont d'Haurs (Givet, France): Bulletin de l'Institut royal des Sciences naturelles de Belgique, Sciences de la Terre, v. 81, pp. 97-128.

Corriga, M.G., Suttner, T.J., Kido, E., Corradini C., Pondrelli, M., and Simonetto, L., 2011, The age of the La Valute limestone-Findenig limestone transition in the La Valute Section (Lower Devonian, Carnic Alps, Italy): Gortania Geologia, Paleontologia, Paletnologia, v. 32, pp. 5-12.
Ernst, A., Königshof, P., Taylor, P., and Bohatý, J., 2011, Microhabitat complexity - an example from Middle Devonian bryozoan-rich sediments: Palaeobiodiversity and Palaeoenvironments, 91, pp. 257-284.

Garcia-Alcalde, J.L., 2011, Subfamilia Teichostrophiinae Harper \& Boucot, 1978c (Strophomenoidea, Strophodontidae) del Devónico Inferior (Emsiense superior) de la Cordillera Cántábrica ( $\mathrm{N}$ de España): Revista Española de Paleontologia, v. 26, no. 1, pp. 25-43.

Ivanov, A., Märss, T., and Kleesment, A., 2011, A new elasmobranch Karksiodus mirus gen. et sp. nov. from the Burtnieki Regional Stage, Middle Devonian of Estonia: Estonian Journal of Earth Scienes, v. 60, no. 1, pp. 22-30.

Izokh, N.G., Yolkin, E.A., Weddige, K., Erina, M.V., and Valenzuela-Ríos, J.I., 2011, Late Pragian and Early Emsian conodont polygnathid species from the Kitab State Geological Reserve sequences (Zeravshan-Gissar Mountainous Area, Uzbekistan): News on Palaeontology and Stratigraphy, Geologiya i Geofizika, 15, pp. 49-63.

Kido, E., Suttner, T.J., 2011, A new project has launched: FWF P23775-B17 "Late Eifelian climate perturbations: Effects on tropical coral communities": Jahrbuch der Geologischen Bundesanstalt, v. 151, no. $3+4,407-416$.

Königshof, P. (ed.), 2009, Devonian Change: Case Studies in Palaeogeography and Palaeoecology: Geological Society of London Special Publication, v. 314, pp. 1-298.

Liao, J.-C., Valenzuela-Ríos, J.I., and Gouwy, S., 2011, Evaluación de la Sucesión de Conodontos Givetienses (Devónico Medio) del Pirineo Central Español: Paleontologia i evolution. Memòria Sp. 5, pp. 435437. Sabadell, ISBN 978-84-615-3001-4.

Martínez-Pérez, C., Valenzuela-Ríos, J. I., Navas-Parejo, P., Liao, J.-C., and Botella, H., 2011, Emsian (Lower Devonian) Polygnathids (Conodont) succession in the Spanish Central Pyrenees: Journal of Iberian Geology, v. 37, no. 1, pp. 45-64, doi: 10.5209/rev_JIGE.2011.v37.n1.4.

Poty, E., Denayer, J., and Mottequin, B., 2011, Middle and Late Frasnian (Late Devonian) sea-level changes in Southern Belgium: their consequences on corals and brachiopods: Kölner Forum für Geologie und Paläontologie, 19, pp. 137-138.

Schemm-Gregory, M., 2011, Lusitanispirifer lusitanensis n. gen. et sp. - A new delthyridoid spirifer and its palaeogeographical implications for the Dornes Syncline (Lower Devonian, Portugal): Bollettino della Società Paleontologica Italiana, v. 50, no. 2, pp. 85-94.

Tolokonnikova, Z., Ernst, A., and Yarahmadzahi, H., 2011, Frasnian bryozoans (Late Devonian) from the Khoshyeilagh Section, Alborz Mountains (Northern Iran): Paläontologische Zeitschrift, 85, pp. 393-405.

Vodrázková, S., Klapper, G., and Murphy, M., 2011, Early Middle Devonian conodont faunas (Eifelian, costatus-kockelianus zones) from the Roberts Mountains and adjacent areas in central Nevada: Bulletin of Geosciences, v. 86, no. 4, pp. 737-764, doi: 10.3140/bull. geosci.1292.

Wongwanich, T., and Boucot, A.J., 2011, Chapter 4, Devonian: in Ridd, M. F., Barber, A. J., and Crow, M. J., eds, The Geology of Thailand, Geological Society of London, pp. 53-70.

Yolkin, E.A., Izokh, N.G., Weddige, K., Erina, M.V., Valenzuela-Ríos, J.I and Apekina, L.S., 2011, Eognathoid and polygnathhid lineales from the Kitab State Geological Reserve sections (Zeravshan-Gissar Mountainous Area, Uzbekistan) as the bases for improvements of Pragian-Emsian Standard conodont zonation: News on Palaeontology and Stratigraphy, Geologiya i Geofizika, 15, pp. 37-45. 